\title{
POTENTIAL FOR NITROUS OXIDE EMISSION MITIGATION FROM SPRINKLING IRRIGATION APPLICATIONS OF CHEMICAL FERTILIZER COMPARED TO FURROW IRRIGATION IN ARID REGION AGRICULTURE
}

\author{
YANG, W. Z. ${ }^{1,2,3,4}-$ KANG, Y. H. ${ }^{1,2^{*}}-$ FENG, Z. W. ${ }^{2}-$ GU, P. ${ }^{3}-$ WEN, H. Y. ${ }^{3}-$ LIU, L. J. ${ }^{3}$ \\ ${ }^{I}$ Institute of Geographic Sciences and Natural Resources Research, Chinese Academy of \\ Sciences, Beijing 100101, China \\ ${ }^{2}$ Inner Mongolia Potato Engineering \& Technology Research Center, College of Life Sciences, \\ Inner Mongolia University, Hohhot 010021, China \\ ${ }^{3}$ Inner Mongolia Key Laboratory of Environmental Chemistry, Inner Mongolia Normal \\ University, Hohhot 010022, China \\ ${ }^{4}$ College of Chemistry and Environmental Sciences, Inner Mongolia Normal University, Hohhot \\ 010022, China \\ *Corresponding author \\ e-mail: doctorbachelar@yeah.net \\ (Received 26 $6^{\text {th }}$ Mar 2019; accepted $13^{\text {th }}$ Jun 2019)
}

\begin{abstract}
Sprinkling water is applied in shorter irrigation intervals and lighter irrigation applications in arid areas. The water-saving irrigation is the primary method of local agricultural production. Since chemical fertilizer is the primary emission source of nitrous oxide $\left(\mathrm{N}_{2} \mathrm{O}\right)$, it is appropriate to verify the general influence of water-saving irrigation on $\mathrm{N}_{2} \mathrm{O}$. Results of the study, conducted in a potato field as the experimental site for two consecutive years, using two different irrigation systems - namely, furrow (FI) and sprinkling-irrigation (SI) with a mineral $\mathrm{N}$ fertilizer (NF) and a control without any fertilizer (Control) are reported. The $\mathrm{N}_{2} \mathrm{O}$ emission fluxes with $\mathrm{NF}$ were higher than those of the control in each irrigation system. On plots where the NF was applied, mean emissions fluxes of $\mathrm{N}_{2} \mathrm{O}$ was $152.02 \mu \mathrm{g} /\left(\mathrm{m}^{2}\right.$ $\mathrm{hr}$ ) in FI, $36.53 \mu \mathrm{g} /\left(\mathrm{m}^{2} \mathrm{hr}\right)$ in SI from 2016 to 2017. The reduction of $\mathrm{N}_{2} \mathrm{O}$ emissions from SI was due to the lower amount of water applied every time and the lower $\mathrm{NO}_{3}{ }^{-} \mathrm{N}$ and $\mathrm{NH}_{4}{ }^{+}-\mathrm{N}$ of soil associated with SI. This work showed that SI is a method that helps save water and mitigates emissions of the atmospheric $\mathrm{N}_{2} \mathrm{O}$ pollutants compared to FI.
\end{abstract}

Keywords: greenhouse gas, moisture, fertilization, emission factor, potato field

\section{Introduction}

Nitrous oxide $\left(\mathrm{N}_{2} \mathrm{O}\right)$ is one of the most significant long-lived greenhouse gases in the atmosphere. The atmospheric $\mathrm{N}_{2} \mathrm{O}$ concentration has increased from $270 \mathrm{ppbv}\left(10^{-9}\right.$ volume ratio) in 1750 to $324 \mathrm{ppbv}$ in 2011, resulting in an increase of $0.17 \mathrm{~W} / \mathrm{m}^{2}$ in radiative forcing. Especially from 2007 to 2011, $\mathrm{N}_{2} \mathrm{O}$ concentration in the atmosphere increased linearly at an annual average rate of 6\% (IPCC, 2013; Schilt et al., 2014). Agricultural production is the primary source of $\mathrm{N}_{2} \mathrm{O}$ emission (Robertson et al., 2000). Agricultural emissions accounted for about $56 \%$ of the total anthropogenic atmospheric $\mathrm{N}_{2} \mathrm{O}$ emissions in 2005 (US-EPA, 2006). The water strategy is one of the essential factors that affect the emissions of $\mathrm{N}_{2} \mathrm{O}$ from agricultural soils. In irrigated soils, the amount of water used and its distribution in the soil influence moisture temporally and spatially. Consequently, different moisture content determines the processes that control 
the amount of $\mathrm{N}$ transported, $\mathrm{N}$ mineralized such as $\mathrm{NO}_{3}{ }^{-} \mathrm{N}$ leaching within the soil. The changes on water and nitrogen in the soil affect the temporal and spatial distribution for various forms of nitrogen and the formation of $\mathrm{N}_{2} \mathrm{O}$. These irrigating systems, for instance, furrow (FI) or sprinkling irrigation (SI), significantly influence the movement of water in the soil because vertical and lateral infiltration are produced simultaneously (Auxiliadora et al., 2018; Naghedifar et al., 2018).

In arid and semiarid areas, FI is one of the most traditional surface irrigation systems because many crops that do not grow in water for long periods are suitable for this irrigation method. Under FI, water is delivered into each strip at a high amount from a head at its upper end to promote the rapid dissolution of fertilizers because of soaking in large quantities of water (Naghedifar et al., 2018). After the irrigation with long intervals and heavy application depths, water flows through the macropores, and most of the soil volume is wetted, temporarily creating the high ratio of anaerobic microsites, even if the small ratio of the ridge top may remain dry.

SI is one of the most popular methods of irrigation worldwide as an efficient and economically viable alternative (Ezequiel et al., 2018), because it offers the precise controlling of irrigation water amount and uniformity to decrease water and $\mathrm{N}$ losses (Lorenzo et al., 2018; José et al., 2018). Sprinkling water is applied on shorter irrigation intervals and lighter irrigation applications. Canopy induced irrigation water redistribution, which influenced the spatial and temporal variability of water in the soil. Irrigation water reaches the surface of the soil after it passes through the developed crop canopy, like precipitation. The wetted front in the soil surface moves downward under capillarity action and only a small part of the soil volume is nearly saturated due to the uniformity of irrigation (Naghedifar et al., 2018; Zapata et al., 2018). The wetted front from the soil surface advances slightly into the soil during sprinkling irrigation (Laura et al., 2008). Consequently, increasing the amount of water from different irrigation systems increases the wetted volume and shape in the soil, which mainly depends on the quantity and rate of applied water. The hydraulic properties in the irrigated soil determine the horizontal and vertical infiltration of water ( $\mathrm{Li}$ et al., 2003; Vázquez et al., 2005). In previous studies, although the influences of moisture on crop growth have been very well recorded in SI and FI systems (Davidson, 1991; Granli and Bockman, 1994), the effects of these different wetted patterns in the soils on $\mathrm{N}_{2} \mathrm{O}$ emissions are not known. So far, the information on $\mathrm{N}_{2} \mathrm{O}$ emissions and the related importance do not appear in the comparison between sprinkling and furrow irrigation soils.

We assumed that the irrigation methods will influence $\mathrm{N}_{2} \mathrm{O}$ emissions because of the different wetted forms in the furrow and sprinkling irrigation soils. In the sprinkled soil, the applied water at low water amount may be beneficial to more aerobic than anaerobic environment. The advance of the wetting front may produce pulses of $\mathrm{N}_{2} \mathrm{O}$ from the furrow-irrigated areas, similar to those observed after irrigation when soil was dry (Diego et al., 2017). Therefore, we doubt that the differences of water distributed between SI and FI soils may occur the different states in $\mathrm{N}_{2} \mathrm{O}$ emissions. In our studies, the objectives were to compare $\mathrm{N}_{2} \mathrm{O}$ emissions in the soils from a potato field with furrow and sprinkling irrigation, and to assess how the two irrigation systems modulated the $\mathrm{N}_{2} \mathrm{O}$ emissions and emission factor of $\mathrm{N}_{2} \mathrm{O}$. In this experiment, the results would help to develop the strategies to mitigate $\mathrm{N}_{2} \mathrm{O}$ emissions from the soils fertilized with chemical fertilizers in irrigated agriculture. 


\section{Materials and methods}

\section{Description of the study site}

The experiment was implemented during the 2016-2017 at the potato experimental farm in the suburbs of Hohhot, Inner Mongolia (latitude $40^{\circ} 45^{\prime} 34^{\prime \prime} \mathrm{N}$, longitude $\left.111^{\circ} 41^{\prime} 56^{\prime \prime} \mathrm{E}\right)$, in the middle of Inner Mongolia Plateau located in the hinterland of the Asian continent (Fig. 1). The soil was a Calcic Haploxerept with a sandy clay loam texture (Soil Survey Staff, 1992). Some physico-chemical properties in the upper (0$30 \mathrm{~cm}$ ) horizon of the soil were: $\mathrm{pH}, 7.79$; organic matter, $0.93 \pm 0.2 \mathrm{~g} / \mathrm{kg}$; bulk density, $1.25 \pm 0.2 \mathrm{~g} / \mathrm{cm}^{3}$; clay, $32 \%$; silt, $20 \%$; and sand, $48 \% ; \mathrm{CaCO}_{3}, 8.54 \pm 0.1 \mathrm{~g} / \mathrm{kg}$. The mean annual precipitation is $335 \mathrm{~mm}$ and the mean annual temperature is $6.7^{\circ} \mathrm{C}$ (averages for the previous 15 years).
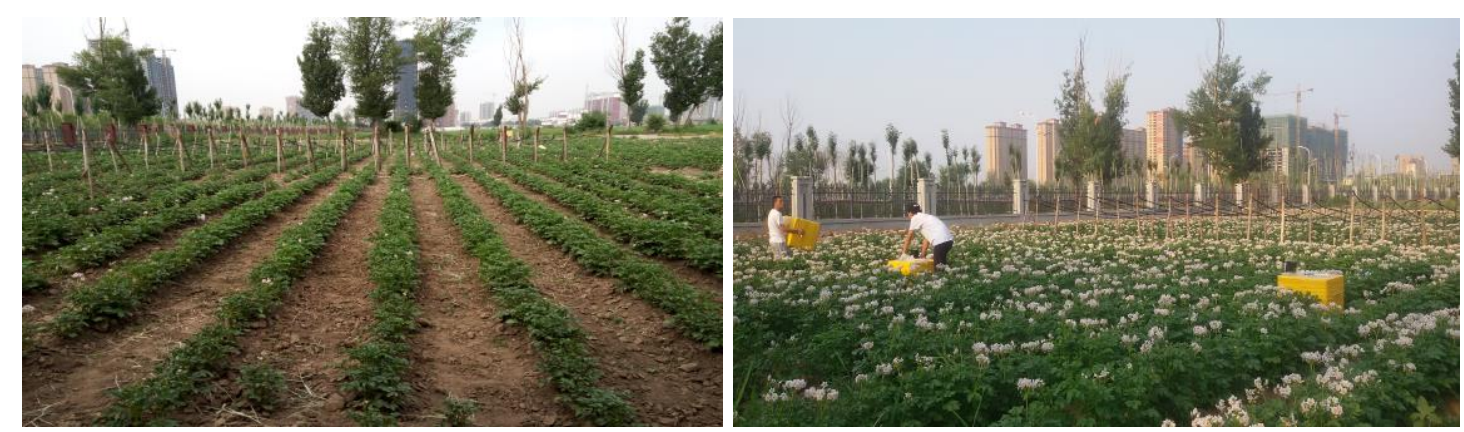

Figure 1. The experimental site and equipments used to collect gases in the potato field

\section{Experimental design and field management}

The experiment was arranged according to a split-plot design. Two main plots $\left(600 \mathrm{~m}^{2}\right)$ were selected in the experimental field with two treatments. Every main plot was divided into six subplots $(5 \times 10 \mathrm{~m})$ in a randomized complete block design with three replicates. The main-plot treatments were different irrigation systems: furrow and sprinkling irrigation. Each mainplot was also split according to the fertilizer treatment applied:(i) N, P, and K compound fertilizer and urea as a chemical fertilizer (NF, $390 \mathrm{~kg}$ $\mathrm{N} / \mathrm{ha}$ ) and (ii) a control without any fertilizer (Control). The amount of applied fertilizer is the local range used by farmers for potato crops $(360-410 \mathrm{~kg} \mathrm{~N} / \mathrm{ha})$. Fertilizers were applied by hand and immediately incorporated into the upper $15 \mathrm{~cm}$ of the soil using a rotovator. Sprinkling irrigation is often used to apply soluble fertilizers, in small amounts, as and when irrigated. Per subplot included five pressure-compensated sprinkling irrigation lines spaced $90 \mathrm{~cm}$ apart. Each sprinkling irrigation line was fitted with a solid set consisting of six full circle impact sprinklers (Elgo 80B2, made in Israel) with a wetting radius of $10 \mathrm{~m}$, spaced $2.8 \mathrm{~m}$ apart, mounted on $1.30 \mathrm{~m}$ risers. A water meter (LXS-20C, TEFEN Manufacture, Nahsholim, Israel) was installed in the main pipe to measure sprinkling water amount in each experimental plot. This method is a popular practice in local farmers.

The experimental site for the furrow irrigation involved five furrows in each subplot, which were spaced $90 \mathrm{~cm}$ apart and ploughed $30 \mathrm{~cm}$ deep. The furrows were enclosed at the end of each experimental site, as irrigation water was intercepted to prevent it from flowing out of the field. The subplots were independent, but irrigated at the same time. The furrows were constructed using a seeding machine. The amount of used 
irrigation water was recorded by water meter on each irrigated subplot after fertilizer application.

A potato crop (Solanum tuberosum L. cv. Favorita) requiring about 105 days to reach maturity was planted by potato seeder on May 25th, 2016 and May 15th, 2017. The potatoes were planted on the raised beds $0.3 \mathrm{~m}$ high and $0.6 \mathrm{~m}$ wide, with the top of $0.3 \mathrm{~m}$ bed wide and with a $0.20 \mathrm{~m}$ spacing between plants in a row and sowing rate of $2250 \mathrm{~kg} / \mathrm{ha}$. The time for potatoes to be harvested is September.

\section{Irrigation management}

The first irrigation began on May 25th, 2016 and May 15th, 2017, immediately after the potatoes were planted. Water application intensity in the first was $40 \mathrm{~mm}$ for sprinkling irrigation. After the potatoes revived, the sprinkling field was irrigated when the mean soil matric potential (SMP) of the $0-20 \mathrm{~cm}$ soil layer decreased to about $-24.5 \mathrm{kPa}$. The distribution of main potato-root zones determined the irrigation duration, which was usually about $1.5 \mathrm{~min}$, with about $10 \mathrm{~mm}$ of water each time at a pressure of $0.1 \mathrm{Mpa}$ by automatic control with computer. Sprinkling irrigation was stopped $20 \mathrm{~d}$ before harvesting.

The date and water amount of furrow irrigation were implemented based on local irrigation practices. Irrigation was uniformly applied three times throughout the crop growing season: once when potatoes were planted and the second in the tuber set stages and third time during the tuber bulking stages. The amount of water applied at each irrigation event was about $200 \mathrm{~mm}$. The total amounts of water applied for sprinkling and furrow irrigation during the study period were 200.7 and $601.8 \mathrm{~mm}$ in 2016, 205 and $593.7 \mathrm{~mm}$ in 2017, respectively. Sprinkling irrigation frequency was higher, while total irrigation water was smaller in the sprinkling-irrigated field than in the furrow irrigated field in the experimental seasons. Sprinkling irrigation always characterizes by the higher frequency with a smaller quota for each event respected to furrow irrigation. Total precipitation was less than $200 \mathrm{~mm}$ during the crop growing season.

\section{Sampling and analysis of $\mathrm{N}_{2} \mathrm{O}$}

The $\mathrm{N}_{2} \mathrm{O}$ fluxes were measured in situ simultaneously from each sprinkling irrigation and furrow irrigation plot using a static opaque chamber method (Yang et al., 2018). The chamber headspace was a 1251 cube $(50 \mathrm{~cm} \times 50 \mathrm{~cm} \times 50 \mathrm{~cm})$. The outer layer of the chamber was covered with sponge and aluminum foil, which is used to prevent the chamber from being heated by sunlight. The chambers were placed inside the square stainless-steel rings $(50 \mathrm{~cm} \times 50 \mathrm{~cm})$ to ensure a good seal without destroying the compactness of the soil. The square stainless-steel rings were inserted into the soil, to a depth of $15 \mathrm{~cm}$. On a day before sampling the gas samples, those rings were taken in order not to disturb the water distribution during irrigation. The chambers were closed for 60 min between 8:00 a.m. and 9:00 a.m. During this time, $\mathrm{N}_{2} \mathrm{O}$ concentrations increased linearly. At $0 \mathrm{~min}, 5 \mathrm{~min}, 10 \mathrm{~min}, 15 \mathrm{~min}$, and $20 \mathrm{~min}$, the gas samples $(100 \mathrm{ml})$ were collected in evacuated three-part polypropylene syringes, respectively. They were taken once per week throughout the potato growing season from planting to harvesting. The air temperature inside the chambers was observed during collecting sample. Soil temperature was monitored in the field using a portable digital thermometer (JM 624, JinMing Instrument Co. Ltd., Tianjin, China) inserted into the 
soil: the monitored data were stored in a data logger. The moisture of soil was measured by the TDR350-indicating instrument (SPECTRUM Inc., ST Petersburg, Florida, USA).

The $\mathrm{N}_{2} \mathrm{O}$ in the samples were measured and analyzed within $12 \mathrm{~h}$ by gas chromatograph (Agilent 6820D, Agilent Corporation, Shanghai, China) that was used two detectors: an electron capture detector (ECD) and a hydrogen flame ionization detector (FID). Its configurations described by Jiao (2015) were implemented for the $\mathrm{N}_{2} \mathrm{O}$ analysis (Jiao et al., 2015).

\section{Soil analysis}

After sampling the gas, the soil in each stainless-steel ring was simultaneously collected and soil $\mathrm{NO}_{3}{ }^{-} \mathrm{N}$ and $\mathrm{NH}_{4}{ }^{+}-\mathrm{N}$ were determined by extracting $8 \mathrm{~g}$ of fresh soil with $60 \mathrm{ml}$ of deionized water and $50 \mathrm{ml}$ of $\mathrm{KCl}(0.01 \mathrm{M})$, respectively. They were measured using a micro-Kjeldahl procedure (Aulakh et al., 2000). SOC was determined by analysing soil extracts using a TOC analyzer (Sievers 5310 C, GE Analytical Instruments, USA) (Lim and Choi, 2014). Precipitation data were collected from the portable weather station located in the potato experimental farm.

\section{Calculation method of $\mathrm{N}_{2} \mathrm{O}$ emissions}

Fluxes of $\mathrm{N}_{2} \mathrm{O}$ was estimated within the closed chamber from the linear increase of gas concentration over sampling time of $0 \mathrm{~min}, 5 \mathrm{~min}, 10 \mathrm{~min}, 15 \mathrm{~min}$, and $20 \mathrm{~min}$ based on $r^{2} \geq 0.90$ while providing the maximum available flux data in the analysis of gas emissions (Jiao et al., 2015). Gas concentrations were converted to mass per unit volume ( $\mu \mathrm{g} \mathrm{N}_{2} \mathrm{O} / \mathrm{uL}$ ) using the Ideal Gas Law at chamber air temperature measured during each sampling event and $0.101 \mathrm{MPa}$. Fluxes of $\mathrm{N}_{2} \mathrm{O}$ were computed as:

$$
F=\frac{\Delta C}{\Delta t} \times V / A \times \propto
$$

where $F$ is the flux rate of $\mathrm{N}_{2} \mathrm{O}\left(\mu \mathrm{g} \mathrm{N}_{2} \mathrm{O}-\mathrm{N} /\left(\mathrm{m}^{2} \mathrm{hr}\right)\right), \Delta C / \Delta t$ denotes the increase or decrease of gas concentration in the chamber $(\mu \mathrm{g} /(\mathrm{L} \mathrm{h})), V$ is the volume of the chamber (L), A is the covered surface area $\left(\mathrm{m}^{2}\right)$, and $\alpha$ is a conversion coefficient for elemental $\mathrm{N}\left(28 / 44\right.$ for $\left.\mathrm{N}_{2} \mathrm{O}\right)(E q .1)$. Gas fluxes which failed linearity test were not included in the data analysis and accounted for $<2 \%$ of the total data set, while gas fluxes that failed significance and detection tests were set to zero flux. A complete discussion of chamber flux method is described in (Adviento-Borbe and Linquist, 2016).

\section{Data statistics and analysis}

The $\mathrm{N}_{2} \mathrm{O}$ emissions were estimated by successive linear interpolation of $\mathrm{N}_{2} \mathrm{O}$ emissions from the soils associated with the different irrigation systems. Statistical analyses were performed using SPSS version 22.0 (SPSS Inc., Chicago, IL, USA). A one-way analysis of variance (ANOVA) was used to evaluate the differences in seasonal and annual cumulative emissions of $\mathrm{N}_{2} \mathrm{O}$ between the different irrigation. Tukey's multiple range tests were used to determine whether significant differences occurred between the treatments at a significance level of 0.05. A two-way ANOVA was used to analyze the effects of treatments and their interactions on $\mathrm{N}_{2} \mathrm{O}$ emissions. Data drafting was run by SigmaPlot 13 and Excel 2016. 


\section{Results}

\section{Changes in precipitation and temperatures}

The frequency of rainfall in crop growing season in 2016 is higher than that in 2017. There was no significant difference in the total rainfall of the crop growing season in 2016 and 2017 ( $\mathrm{p}>0.05$ ), which were $196.6 \mathrm{~mm}$ and $198.8 \mathrm{~mm}$, respectively. The atmospheric temperature showed a consistent trend of change from May to September in 2016 and 2017. The temperature began to increase gradually in April and was higher from July to August than other months (Fig. 2).

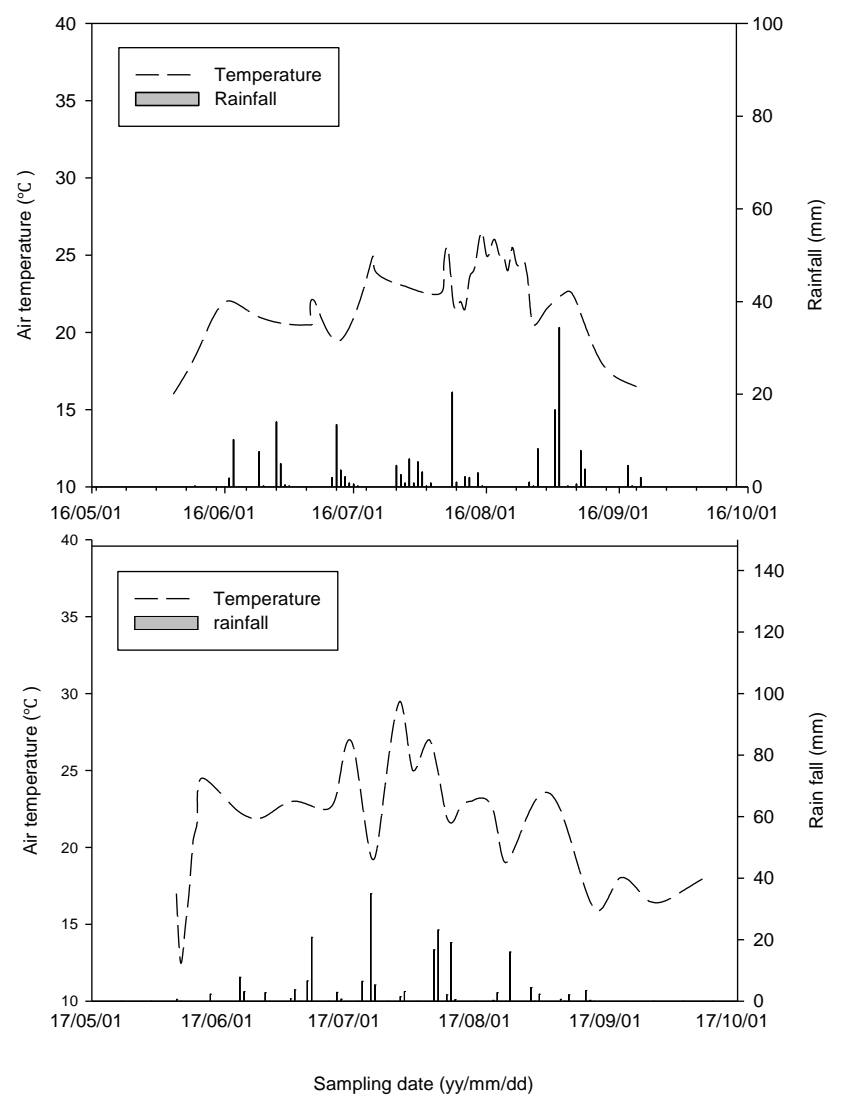

Figure 2. Variable amount of temperature and precipitation in the potato experimental farm in 2016 and 2017

\section{Variation relationship between $\mathrm{N}_{2} \mathrm{O}$ emission fluxes and the moisture or temperature in the soils of SI and FI}

The potato field under four treatments from sprinkling irrigation systems and furrow irrigation systems exhibited a similar trend in $\mathrm{N}_{2} \mathrm{O}$ emission fluxes. A significant emission peak of $\mathrm{N}_{2} \mathrm{O}$ was detected in July and August throughout the testing stage from 2016 to 2017 (Fig. 3). Both the chemical fertilizer applied and the irrigation methods used affected the $\mathrm{N}_{2} \mathrm{O}$ emission fluxes (Fig. 3). The NF soils from SI exhibited the highest $\mathrm{N}_{2} \mathrm{O}$ emission fluxes, with $613.5 \mu \mathrm{g} /\left(\mathrm{m}^{2} \mathrm{hr}\right)$ in July 2017. The highest $\mathrm{N}_{2} \mathrm{O}$ emission fluxes were produced with $1047.9 \mu \mathrm{g} /\left(\mathrm{m}^{2} \mathrm{hr}\right)$ from FI in the NF soils in July 2017. For the fertilization treatment and control under furrow irrigation system, the $\mathrm{N}_{2} \mathrm{O}$ fluxes observed were higher than that in the sprinkling irrigation system in two crop 
growing seasons, respectively. The $\mathrm{N}_{2} \mathrm{O}$ emission fluxes of the fertilization treatment were higher than those of the control treatment in each irrigation system during the experimental period (Fig. 3).
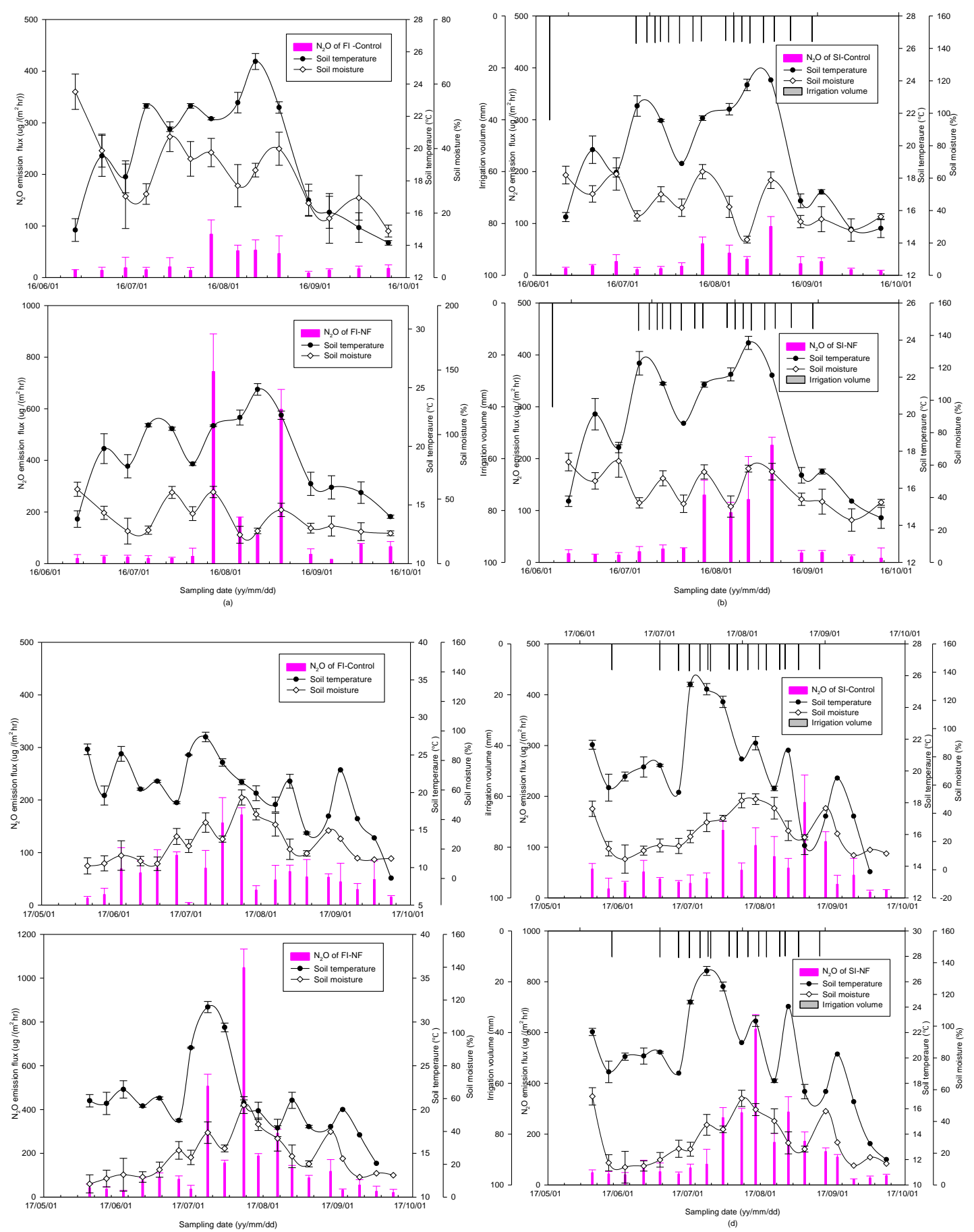

Figure 3. Variation relationship between $\mathrm{N}_{2} \mathrm{O}$ emission fluxes and the soil moisture or soil temperature in Control and NF in 2016 from FI (a) and SI (b), in 2017 from FI (c) and SI (d). (SI-NF and FI-NF refer to the treatment of fertilization from sprinkling irrigation and furrow irrigation. SI-Control and FI-Control refer to the treatment of no fertilization from sprinkling irrigation and furrow irrigation. Vertical bars indicate standard errors. The y-axes in the graphs $(a)-(d)$ are on different scales) 
The variables of soil moisture and temperature exhibited generally consistent trends with $\mathrm{N}_{2} \mathrm{O}$ emission fluxes from two irrigation systems. The soil moisture and temperature were higher, and $\mathrm{N}_{2} \mathrm{O}$ emission fluxes of soils of two irrigation systems were higher in July and August than in May-June and in September (Fig. 3). During the irrigation period (from May to September), mean moisture of soil remained 45.9 and $44.5 \%$ under the furrow irrigation fertilization (NF) and furrow irrigation control (Control) system, and 39.7 and $34.3 \%$ under the sprinkling irrigation fertilization (NF) and sprinkling irrigation control (Control) system in 2016. The mean moisture of soil remained 26.1 and $26.6 \%$ under the NF and Control system from FI, and 24.6 and $23.3 \%$ under the NF and Control system from SI in 2017 (Fig. 3). Mean moisture was generally higher in NF and Control of FI than NF and Control plots of SI. There was no significant effect of two irrigation systems on the average daily soil temperature in the $0-30 \mathrm{~cm}$ soil layer from May to September $(p>0.05)$. There was no significant difference in soil temperature and moisture content for fertilized soil and soil without fertilizer of each irrigation system $(\mathrm{p}>0.05)$.

\section{Cumulative $\mathrm{N}_{2} \mathrm{O}$ emissions in both irrigation systems}

A significant difference in cumulative $\mathrm{N}_{2} \mathrm{O}$ emissions of soils from the two irrigation systems was measured during the potato growing season in $2016(\mathrm{~F}=13.84, \mathrm{p}<0.001)$ and $2017(\mathrm{~F}=6.49, \mathrm{p}<0.001)$. The soils in Control of SI $(\mathrm{F}=47.0, \mathrm{p}<0.001), \mathrm{NF}$ of SI $(\mathrm{F}=7.8, \mathrm{p}<0.01)$, Control of FI $(\mathrm{F}=57.5, \mathrm{p}<0.001)$, and NF of FI $(\mathrm{F}=3.0, \mathrm{p}<0.05)$ showed significant differences in the inter-annual cumulative $\mathrm{N}_{2} \mathrm{O}$ emissions (Fig. 4). The cumulative $\mathrm{N}_{2} \mathrm{O}$ emissions were significantly higher for $\mathrm{NF}$ and Control from FI than for $\mathrm{NF}$ and Control from SI over the annual sunflower growing season. The cumulative $\mathrm{N}_{2} \mathrm{O}$ emissions in the fertilized soil were higher than that of the controlled soils each irrigation system. The cumulative $\mathrm{N}_{2} \mathrm{O}$ emissions were 373.03 and $425.12 \mathrm{mg} / \mathrm{m}^{2}$ for the FI with $\mathrm{NF}$ in 2016 and 2017. The cumulative $\mathrm{N}_{2} \mathrm{O}$ emissions were 150.40 and $252.01 \mathrm{mg} / \mathrm{m}^{2}$ for SI with NF from 2016 to 2017, respectively. The cumulative $\mathrm{N}_{2} \mathrm{O}$ emissions from SI with NF were 59.68\% and 40.72\% lower than those from FI with NF for 2016 and 2017, respectively. The cumulative $\mathrm{N}_{2} \mathrm{O}$ emissions of the Control soil from SI were 74.51 and $177.05 \mathrm{mg} / \mathrm{m}^{2}$, and were $2.12 \%$ (2016) and 2.10\% (2017) lower than that of the Control soil from FI in May - September during the annual potato field tested stage (Fig. 4). The cumulative $\mathrm{N}_{2} \mathrm{O}$ emissions varied significantly with different irrigation systems throughout the potato experimental period. Sprinkling irrigation significantly reduced $\mathrm{N}_{2} \mathrm{O}$ emissions.

\section{Emission factor of $\mathrm{N}_{2} \mathrm{O}$}

Emission factor of $\mathrm{N}_{2} \mathrm{O}(\mathrm{EF})$ denotes the percentage of nitrogen lost in the form of $\mathrm{N}_{2} \mathrm{O}$ gas in nitrogenous fertilizer, and can better evaluate the $\mathrm{N}_{2} \mathrm{O}$ emission ratio of the fertilizers applied. EF of nitrogen fertilizer has been widely used in estimating regional and global $\mathrm{N}_{2} \mathrm{O}$ emission inventories from farmland. The EF increased with $\mathrm{N}_{2} \mathrm{O}$ emission due to increasing nitrogen fertilizer applied per unit area. EF from furrow irrigation and sprinkling irrigation in our study was $0.76 \%$ and $0.20 \%$ in $2016,0.62 \%$ and $0.19 \%$ in 2017, respectively (Fig. 5). Compared with furrow irrigation, sprinkling irrigation can significantly reduce EF. The EF from sprinkling irrigation was $73.68 \%$ and $69.35 \%$ lower than that of furrow irrigation in 2016 and 2017. There was no significant difference in the inter-annual EF in furrow irrigation or sprinkling irrigation compared to soil air. 


$$
-10971 \text { - }
$$

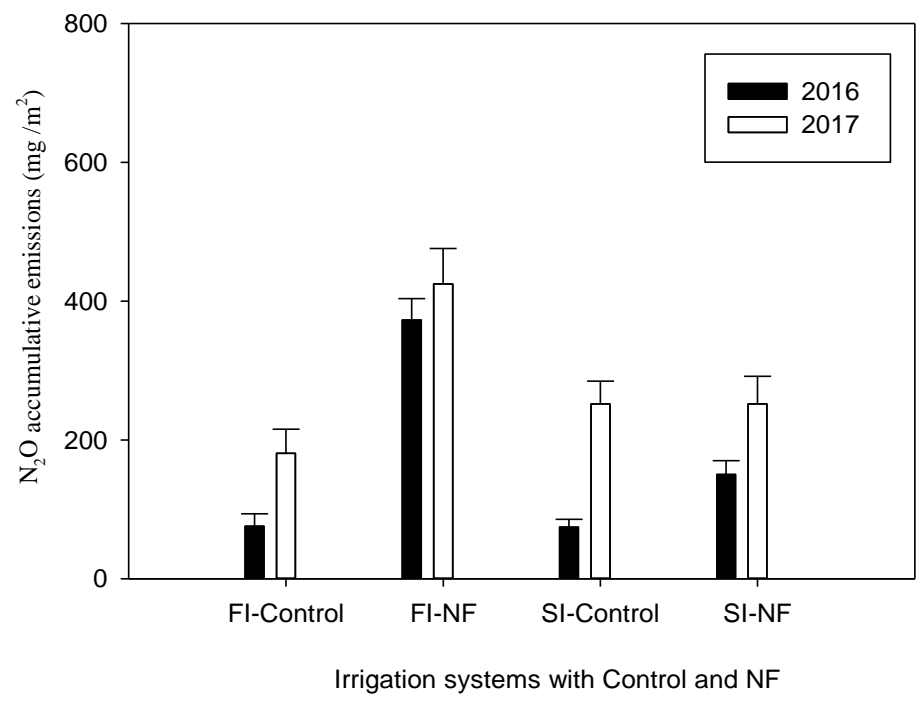

Figure 4. Cumulative $\mathrm{N}_{2} \mathrm{O}$ emissions varied significantly in Control and $\mathrm{NF}$ with FI and SI throughout the potato experimental period. (SI-NF and FI-NF refer to the treatment of fertilization from sprinkling irrigation and furrow irrigation. SI-Control and FI-Control refer to the treatment of no fertilization from sprinkling irrigation and furrow irrigation. Vertical bars indicate standard errors for each irrigation system)

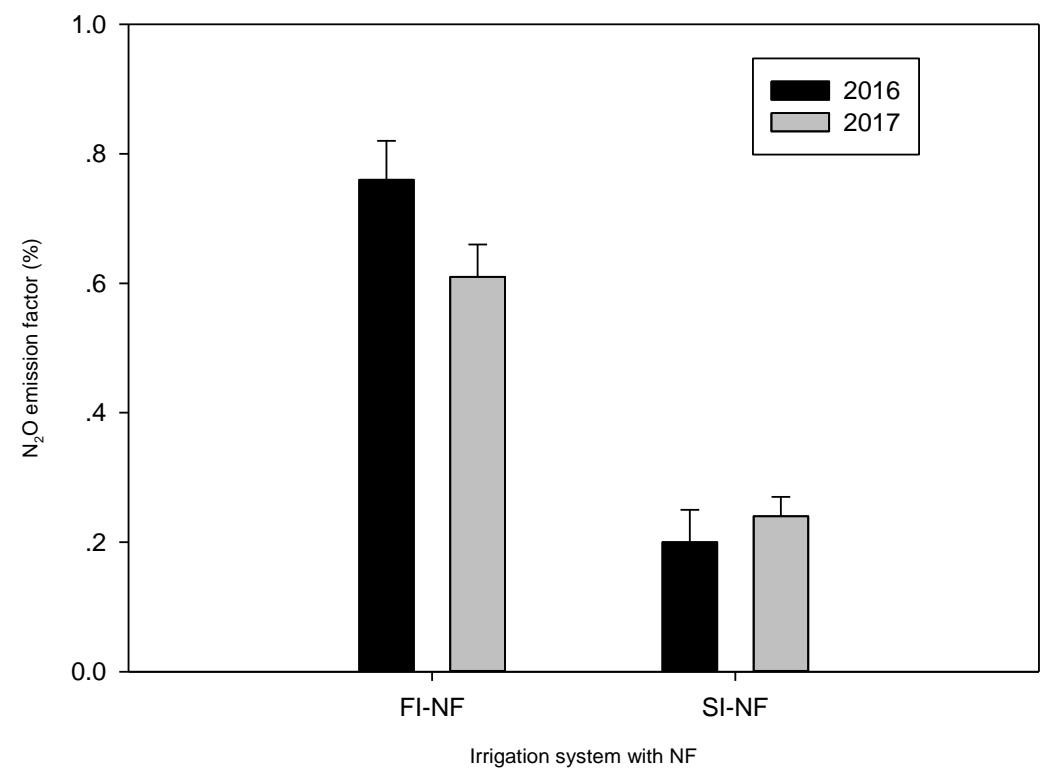

Figure 5. Emission factor of $\mathrm{N}_{2} \mathrm{O}$ varied between FI-NF and SI-NF in 2016 and 2017. (SI-NF and FI-NF refer to the treatment of fertilization from sprinkling irrigation and furrow irrigation. Vertical bars indicate standard errors for each irrigation system)

\section{Discussion}

\section{Seasonal variation of $\mathrm{N}_{2} \mathrm{O}$ emissions in two irrigation systems}

The biggest $\mathrm{N}_{2} \mathrm{O}$ emission pulses were generated and there are higher emission rate in July and August during the season of vigorous potato growth from 2016 to 2017, in both the sprinkling irrigation and furrow irrigation treatments. Seasonal dynamics of 
$\mathrm{N}_{2} \mathrm{O}$ emissions fluxes were consistent with the changes of moisture and temperature in soil that were greater in July - August than in May-June and September-October (Fig. 3). These discoveries are consistent with the results of Kallenbach et al. (2010) in the soils from other arid and semiarid areas (Kallenbach et al., 2010). The production and consumption of $\mathrm{N}_{2} \mathrm{O}$ from the soils are affected via the processes of nitrification and denitrification with microorganisms participating. These processes are all related to soil temperature and moisture (Firestone and Davidson, 1989). Soil moisture controls the biotic and abiotic processes, and operates a critical regulation function in the microbial activities of soils, for instance, $\mathrm{N}$ mineralization, nitrification and denitrification that are all quantitatively influenced by the applied irrigation methods (Sánchez-Martín et al., 2008). Climate and soil abiotic factors: soil temperature and moisture, can affect the dynamic changes of $\mathrm{N}_{2} \mathrm{O}$, with visible seasonal characteristics, in particular, in water transport.

\section{$\mathrm{N}_{2} \mathrm{O}$ emissions fluxes in the fertilized and control soils from sprinkling irrigation and furrow irrigation}

Mean emissions fluxes of $\mathrm{N}_{2} \mathrm{O}$ was $152.02 \mu \mathrm{g} /\left(\mathrm{m}^{2} \mathrm{hr}\right)$ in furrow irrigation, $36.53 \mu \mathrm{g} /\left(\mathrm{m}^{2} \mathrm{hr}\right)$ in sprinkling irrigation for fertilization treatment from 2016 to 2017. Change of irrigation mode affects $\mathrm{N}_{2} \mathrm{O}$ source emission from farmland soil. In furrow irrigation, the peak value of $\mathrm{N}_{2} \mathrm{O}$ emissions in the $\mathrm{NF}$ was four times higher than in sprinkling irrigation. Sprinkling irrigation compared with traditional furrow irrigation, significantly reduced $\mathrm{N}_{2} \mathrm{O}$ emission from potato fields (Fig. 4). The amount of applied water in furrow irrigation was more significant than the saturated hydraulic conductivity in the soils, with furrows remaining flooded for several hours. The $\mathrm{NH}_{4}{ }^{+}-\mathrm{N}$ from the NF in the wetting soils was fleetly nitrified, increasing the concentration of $\mathrm{NO}_{3}{ }^{-}-\mathrm{N}$. In FI, the high rate of used water quickly dissolved these fertilizers and produced a great deal of $\mathrm{NH}_{4}{ }^{+}-\mathrm{N}$ and $\mathrm{NO}_{3}{ }^{-} \mathrm{N}$ on the surface layer of the soil profile. Rapidly dissolving a lot of fertilizer would partly illustrate the significantly greater $(\mathrm{P}<0.05) \mathrm{NO}_{3}{ }^{-}-\mathrm{N}$ and $\mathrm{NH}_{4}{ }^{+}-$ $\mathrm{N}$ concentration found in furrow irrigation system than in sprinkling irrigation system (Table 1). The essential differences between the concentration of $\mathrm{NO}_{3}{ }^{-}-\mathrm{N}$ and $\mathrm{NH}_{4}{ }^{+}-\mathrm{N}$ of the soil have emerged in the decision on irrigation strategy. The process of soil nitrogen conversion is different from that of $\mathrm{N}_{2} \mathrm{O}$ emission between sprinkling irrigation and furrow irrigation. Tensiometers controlled the sprinkling irrigation. The irrigation was triggered when SMP at $0.2 \mathrm{~m}$ depth directly under the sprinkling emitters reached $24.5 \mathrm{kPa}$. The irrigation was stopped when the amount of water applied to each irrigation event was about $10 \mathrm{~mm}$. Values for the soil $\mathrm{NO}_{3}{ }^{-} \mathrm{N}$ and $\mathrm{NH}_{4}{ }^{+}-\mathrm{N}$ concentration in the upper $10 \mathrm{~cm}$ layer for the same fertilizer treatment generally remained lower on NF from SI than FI (Table 1). The $\mathrm{NO}_{3}{ }^{-}-\mathrm{N}$ and $\mathrm{NH}_{4}{ }^{+}-\mathrm{N}$ that will not be leached were concentrated in the root zone of potato under sprinkling irrigation. The $\mathrm{NO}_{3}{ }^{-} \mathrm{N}$ and $\mathrm{NH}_{4}{ }^{+}-\mathrm{N}$ are beneficial to the uptake of potato due to the low amount of water from sprinkling irrigation. The results of Wang et al.'s (2012) research are consistent with our study (Wang et al., 2012). The concentration of $\mathrm{NO}_{3}^{-}-\mathrm{N}$ and $\mathrm{NH}_{4}{ }^{+}-\mathrm{N}$ in furrow irrigation soil is significantly higher than that in water-saving irrigation soil. Sprinkling irrigation reduces the concentration of $\mathrm{NO}_{3}^{-}-\mathrm{N}$ and $\mathrm{NH}_{4}{ }^{+}-\mathrm{N}$, inhibits denitrification and reduces $\mathrm{N}_{2} \mathrm{O}$ emissions. High concentrations of $\mathrm{NO}_{3}{ }^{-}-\mathrm{N}$ and $\mathrm{NH}_{4}{ }^{+}-\mathrm{N}$ trigger higher $\mathrm{N}_{2} \mathrm{O}$ emissions during nitrification and denitrification (Sánchez-Martín et al., 2008). In our study, high $\mathrm{NO}_{3}^{-}-\mathrm{N}$ and $\mathrm{NH}_{4}{ }^{+}-\mathrm{N}$ contents in furrow irrigation resulted in high $\mathrm{N}_{2} \mathrm{O}$ emission. 
Table 1. Basic physical and chemical properties of soil from sprinkling irrigation and furrow irrigation

\begin{tabular}{c|c|c|c|c|c}
\hline Year & Treatments & $\begin{array}{c}\text { Bulk density } \\
\left(\mathbf{g ~ c m}^{-3}\right)\end{array}$ & $\begin{array}{c}\text { Porosity } \\
(\mathbf{\%})\end{array}$ & $\begin{array}{c}\mathbf{N H}^{+} \mathbf{- N} \\
\left(\mathbf{m g ~ k g}^{-\mathbf{1}}\right)\end{array}$ & $\begin{array}{c}\mathbf{N O}^{-}-\mathbf{N} \\
\left(\mathbf{m g ~ k g}^{-\mathbf{1}} \mathbf{)}\right.\end{array}$ \\
\hline \multirow{3}{*}{2016} & FI-NF & $1.34 \pm 0.07 \mathrm{a}$ & $48.13 \pm 1.40 \mathrm{a}$ & $7.09 \pm 1.10 \mathrm{a}$ & $34.28 \pm 1.25 \mathrm{a}$ \\
& SI-NF & $1.21 \pm 0.03 \mathrm{~b}$ & $49.86 \pm 0.53 \mathrm{~b}$ & $6.46 \pm 1.00 \mathrm{~b}$ & $22.98 \pm 1.60 \mathrm{~b}$ \\
& FI-Control & $1.35 \pm 0.05 \mathrm{a}$ & $49.23 \pm 0.62 \mathrm{c}$ & $6.64 \pm 1.22 \mathrm{c}$ & $21.76 \pm 1.21 \mathrm{c}$ \\
& SI-Control & $1.19 \pm 0.01 \mathrm{~b}$ & $52.58 \pm 0.75 \mathrm{~d}$ & $6.08 \pm 1.43 \mathrm{~d}$ & $16.64 \pm 1.36 \mathrm{e}$ \\
\hline \multirow{3}{*}{2017} & FI-NF & $1.29 \pm 0.02 \mathrm{c}$ & $50.42 \pm 2.30 \mathrm{e}$ & $6.95 \pm 1.35 \mathrm{e}$ & $73.66 \pm 2.21 \mathrm{f}$ \\
& SI-NF & $1.17 \pm 0.02 \mathrm{~b}$ & $55.15 \pm 1.80 \mathrm{f}$ & $6.25 \pm 1.06 \mathrm{f}$ & $37.76 \pm 1.13 \mathrm{~g}$ \\
& FI-Control & $1.29 \pm 0.01 \mathrm{c}$ & $50.09 \pm 1.20 \mathrm{c}$ & $6.76 \pm 1.40 \mathrm{~b}$ & $34.41 \pm 2.05 \mathrm{~h}$ \\
& SI-Control & $1.21 \pm 0.01 \mathrm{~b}$ & $53.17 \pm 0.38 \mathrm{~d}$ & $6.21 \pm 1.20 \mathrm{~d}$ & $30.47 \pm 1.97 \mathrm{i}$ \\
\hline
\end{tabular}

SI-NF and FI-NF refer to the treatment of fertilization from sprinkling irrigation and furrow irrigation. SI-Control and FI-Control refer to the treatment of no fertilization from sprinkling irrigation and furrow irrigation. $\mathrm{NH}_{4}{ }^{+}-\mathrm{N}$ and $\mathrm{NO}_{3}{ }^{-}-\mathrm{N}$ are seasonal mean. Bulk density and porosity are the value at the end of the growing season

Comparing sprinkling irrigation with furrow irrigation in potato field, soil bulk density under sprinkling irrigation $\left(1.17 \mathrm{~g} / \mathrm{cm}^{3}\right)$ is lower than that under furrow irrigation $\left(1.29 \mathrm{~g} / \mathrm{cm}^{3}\right.$ ) from 2016 to 2017 (Table 1). Sprinkling irrigation compared with furrow irrigation increases soil porosity, improves soil permeability. The topsoil in sprinkling irrigation fields was looser than that in furrow irrigation fields (Sun et al., 2008). Sprinkling irrigation is one of the water-saving irrigation methods widely adopted in agricultural production. The environmental conditions of soils in sprinkling irrigation were similar to that of drip irrigation ( $\mathrm{Lv}$ et al., 2010), and favored nitrification, contributing to lower emissions of N oxides (Sánchez-Martín et al., 2008). Both the high consumption and frequency of used water in the furrow irrigation strategy produced the high moisture of soil in the plots. The high moisture in the soils resulted in the emergence of a high proportion of anaerobic environment. High soil moisture not only stimulates soil microbial activity, but also reduces the flow of oxygen in soil, leading to nitrification and denitrification. Use of furrow irrigation gave higher $\mathrm{N}_{2} \mathrm{O}$ emission losses than drip irrigation (Sánchez-Martín et al., 2008). Different infiltration and redistribution patterns of irrigation water result in different distribution patterns of soil water in time, horizon and vertical depth, which have an important impact on the production and emission of $\mathrm{N}_{2} \mathrm{O}$ and its spatial and temporal distribution. Under drip irrigation, as water supply is low, the process of soil $\mathrm{N}_{2} \mathrm{O}$ production from denitrification will be limited, and the $\mathrm{N}_{2} \mathrm{O}$ emission will be reduced (Kallenbach et al., 2010; Sánchez-Martín et al., 2010). Soil in furrow-irrigated potato fields emits more $\mathrm{N}_{2} \mathrm{O}$ than that in sprinkling-irrigated. Sprinkling irrigation can reduce $\mathrm{N}_{2} \mathrm{O}$ emission from farmland soil.

The used NF treatment in the potato field also had a significant impact on the results achieved. The concentration of $\mathrm{NH}_{4}{ }^{+}-\mathrm{N}$ and $\mathrm{NO}_{3}{ }^{-}-\mathrm{N}$ was significantly $(\mathrm{P}<0.05)$ greater in the fertilization treatment than in the Control for sprinkling irrigation and furrow irrigation, respectively (Table 1). The $\mathrm{N}_{2} \mathrm{O}$ emissions of soils were commonly higher in the fertilization treatment than in the Control in sprinkling irrigation and furrow irrigation throughout the testing stage (Fig. 3). In irrigated agriculture, both the availability of water and $\mathrm{N}$ fertilizers has an essential effect on $\mathrm{N}_{2} \mathrm{O}$ emissions. Higher concentrations of $\mathrm{NH}_{4}{ }^{+}$and $\mathrm{NO}_{3}{ }^{-}$were detected in the soils of $\mathrm{NF}$ compared with the 
soil of no fertilizer (Vallejo et al., 2005). The effect of the ions from nitrification and denitrification processes caused higher $\mathrm{N}_{2} \mathrm{O}$ emissions in the soils with chemical fertilizer compared with the soils of no fertilizer in drip irrigation and furrow irrigation systems (Sánchez-Martín et al., 2008).

\section{Emission factor of $\mathrm{N}_{2} \mathrm{O}$ in two irrigation systems}

In our study, mean emission factor of $\mathrm{N}_{2} \mathrm{O}$ from nitrogenous fertilizer for two-year growth period in potato fields is 0.20 and $0.69 \%$ in sprinkling irrigation and furrow irrigation, respectively. Statistics such as Xu et al. (2016) show that the $\mathrm{N}_{2} \mathrm{O}$ emission factor of nitrogen fertilizer is $0.50 \% \sim 0.82 \%$ during the growth period of summer maize, $0.61 \% \sim 1.13 \%$ in a vegetable field in the arid area (Xu et al., 2016). The EF of $\mathrm{N}_{2} \mathrm{O}$ from the potato field of furrow irrigation in our study is in the range of $\mathrm{EF}$ from $\mathrm{Xu}$ et al. (2016) in the upland field. The $\mathrm{EF}$ of $\mathrm{N}_{2} \mathrm{O}$ in potato field from sprinkling irrigation was significantly lower than that in the soils of the upland field, and it was $61 \%$ lower than the lowest $\mathrm{EF}(0.61 \%)$ of $\mathrm{N}_{2} \mathrm{O}$ in vegetable soil and $81 \%$ lower than the highest $\mathrm{EF}$ $(1.13 \%)$ of $\mathrm{N}_{2} \mathrm{O}$. Sprinkling irrigation significantly reduces $\mathrm{N}_{2} \mathrm{O}$ emissions.

Kang and Eltahir (2018) use the Massachusetts Institute of Technology (MIT) Regional Climate Model (MRCM) to perform simulations for the historical period (1975-2005), as well as future climate (2070-2100) assuming two scenarios of GHG emissions with furrow irrigation which cools surface temperature and moistens surface air, but boosts integrated measures of temperature and humidity, and hence enhances intensity of heatwaves. China is currently one of the largest contributors to the emissions of greenhouse gases, with potentially serious implications to its population (Kang and Eltahir, 2018). Sprinkling irrigation in China is widely used to reduce these greenhouse gas emissions.

The irrigation strategy had an important impact on the pattern of $\mathrm{N}_{2} \mathrm{O}$ emissions. The choice of an irrigation system is regarded as a critical way of saving water in arid and semiarid regions and maintaining optimal crop yield. In this experiment, sprinkling irrigation has been demonstrated that it can also be used as a tool for mitigating emissions of $\mathrm{N}_{2} \mathrm{O}$. To date, no results have been published comparing sprinkling and furrow irrigation. Although our results indicate that the $\mathrm{N}_{2} \mathrm{O}$ emission pattern of sprinkling irrigation contributed to lower emissions on $\mathrm{N}_{2} \mathrm{O}$, many studies will be essential to assess the effect of some parameters related to sprinkling irrigation. These parameters include soil characteristics, especially hydraulic conductivity of affecting water distribution. Moreover, as sprinkling irrigation is frequently combined with applied chemical fertilizer, further work is needed to assess the influence of frequency, rate and type of $\mathrm{N}$ fertilized on $\mathrm{N}_{2} \mathrm{O}$ emissions via sprinkling irrigation.

\section{Conclusions}

This study demonstrated that the choice of irrigation strategy had a significant effect on $\mathrm{N}_{2} \mathrm{O}$ emissions. Sprinkling irrigation saves water and also helps to reduce the production of $\mathrm{N}_{2} \mathrm{O}$. Therefore, it can be regarded as an effective method for mitigating the gas loss in the soils of agroecosystems in arid and semiarid areas. Nevertheless, more field studies are needed to assess the influence of the new irrigation technologies on $\mathrm{N}_{2} \mathrm{O}$ emissions and the comprehensive influence of using both water and $\mathrm{N}$. 
Acknowledgements. The National Natural Science Foundation of China under grant number 41765010, the National Key Research and Development Program of China under grant number 2016YFC0400105, the Inner Mongolia Youth Innovative Talent Training Program of the Prairie Excellence Project 2016 funded this research and Program for Young Talents of Science and Technology in Universities of Inner Mongolia Autonomous Region.

\section{REFERENCES}

[1] Adviento-Borbe, M. A. A., Linquist, B. (2016): Assessing fertilizer N placement on $\mathrm{CH}_{4}$ and $\mathrm{N}_{2} \mathrm{O}$ emissions in irrigated rice systems. - Geoderma 266: 40-45.

[2] Aulakh, M. S., Khera, T. S., Doran, J. W. (2000): Yields and nitrogen dynamics in a ricewheat system using green manure and inorganic fertilizer. - Soil Science Society America Journal 64: 1867-1876.

[3] Auxiliadora, C., Juan, H., Jesús, A. B., Glen, R. (2018): Sensor-based assessment of soil salinity during the first years of transition from flood to sprinkler irrigation. - Sensors 616: 1-18.

[4] Davidson, E. A. (1991): Fluxes of Nitrous Oxide and Nitric Oxide from Terrestrial Ecosystems. - In: Rogers, J. E., Whitman, W. B. (eds.) Microbial Production and Consumption of Greenhouse Gases: Methane, Nitrous Oxides and Halomethanes. American Society for Microbiology, Washington, pp. 219-235.

[5] Diego, A., Alberto, S. C., Gemma, A., Antonio, V. (2017): Rainfall amount and distribution regulate DMPP effects on nitrous oxide emissions under semiarid Mediterranean conditions. - Agriculture Ecosystems \& Environment 238: 36-45.

[6] Ezequiel, S., Antonio, P. D. C., Tarlei, A. B., José, A. F., Richard, K., Bruno, M. (2018): Test methods for characterising the water distribution from irrigation sprinklers: Design, evaluation and uncertainty analysis of an automated system. - Biosystems Engineering 169: 42-56.

[7] Firestone, M. K., Davidson, E. A. (1989): Microbial Basin of $\mathrm{NO}$ and $\mathrm{N}_{2} \mathrm{O}$ Production and Consumption in Soil. - In: Andreae, M. O., Schimel, D. S. (eds.) Exchange of Trace Gases between Terrestrial Ecosystem and the Atmosphere. Wiley, London, pp. 7-21.

[8] Granli, T., Bockman, O. C. (1994): Nitrogen oxide from agriculture. - Norwegian Journal of Agricultural Sciences 12: 7-127.

[9] IPCC (2013): Climate Change 2013: The Physical Science Basis. - In: Stocker, T. F., Qin, D., Plattner, G. K., Tignor, M., Allen, S. K., Boschung, J., Nauels, A., Xia, Y., Bex, V., Midgley, P. M. (eds.) Contribution of Working Group I to the Fifth Assessment Report of the Intergovernmental Panel on Climate Change. Cambridge University Press, New York.

[10] Jiao, Y., Hou, J. H., Zhao, J. H., Yang, W. Z. (2015): Cropland age from grassland conversion to cropland affects nitrous oxide emission. - Acta Agriculturae Scandinavica, Section B -Soil \& Plant Science 65: 566-574.

[11] José, C., Eva, T. M., Francisco, M. (2018): Sprinkler irrigation frequency affects maize yield depending on irrigation time. - Agronomy Journal 110: 1862-1873.

[12] Kallenbach, C. M., Rolston, D. E., Horwath, W. R. (2010): Cover cropping affects soil $\mathrm{N}_{2} \mathrm{O}$ and $\mathrm{CO}_{2}$ emissions differently depending on type of irrigation. - Agriculture Ecosystems \& Environment 137: 251-260.

[13] Kang, S. C., Eltahir, E. A. B. (2018): North China Plain threatened by deadly heatwaves due to climate change and irrigation. - Nature Communications 9: 2894.

[14] Laura, S. M., Augusto, A., Alejandro, B., Lourdes, G. T., Antonio, V. (2008): Influence of drip and furrow irrigation systems on nitrogen oxide emissions from a horticultural crop. - Soil Biology \& Biochemistry 40: 1698-1706.

[15] Li, J., Zhang, J., Ren, L. (2003): Water and nitrogen distribution as affected by fertigation of ammonium nitrate from a point source. - Irrigation Science 22: 19-30. 
[16] Lim, S. S., Choi, W. J. (2014): Changes in microbial biomass, $\mathrm{CH}_{4}$ and $\mathrm{CO}_{2}$ emissions, and soil carbon content by fly ash co-applied with organic inputs with contrasting substrate quality under changing water regimes. - Soil Biology \& Biochemistry 68: 494502.

[17] Lorenzo, D. M., Martina, M., Alex, C. B., Tiago, A. K., Cleber, M. A. (2018): Classification of rice grains of lowland cultivars grown under flood irrigation and sprinkler irrigation. - Engenharia Agrícola 38: 599-605.

[18] Lv, G. H., Kang, Y. H., Li, L., Wan, S. Q. (2010): Effect of irrigation methods on root development and profile soil water uptake in winter wheat. - Irrigation Science 28: 387 398.

[19] Naghedifar, S. M., Ziaei, A. N., Ansari, H. (2018): Simulation of irrigation return flow from a Triticale farm under sprinkler and furrow irrigation systems using experimental data: A case study in arid region. - Agricultural Water Management 210: 185-197.

[20] Robertson, G. P., Paul, E. A., Harwood, R. R. (2000): Greenhouse gases in intensive agriculture: Contributions of individual gases to the radiative forcing of the atmosphere. Science 289: 1922-1925.

[21] Sánchez-Martín, L., Vallejo, A., Dick, J., Skiba, U. M. (2008): The influence of soluble carbon and fertilizer nitrogen on nitric oxide and nitrous oxide emissions from two contrasting agricultural soils. - Soil Biology \& Biochemistry 40: 142-151.

[22] Sánchez-Martín, L., Meijide, A., Garcia-Torres, L., Vallejo, A. (2010): Combination of drip irrigation and organic fertilizer for mitigating emissions of nitrogen oxides in semiarid climate. - Agriculture Ecosystems \& Environment 137: 99-107.

[23] Schilt, A., Brook, E. J., Bauska, T. K., Baggenstos, D., Fischer, H., Joos, F., Petrenko, V. V., Schaefer, H., Schmitt, J., Severinghaus, J. P., Spahni, R., Stocker, T. F. (2014): Isotopic constraints on marine and terrestrial $\mathrm{N}_{2} \mathrm{O}$ emissions during the last deglaciation. - Nature 516: 234-237.

[24] Soil Survey Staff. (1992): Keys to Soil Taxonomy. Sixth Ed. - USDA, Washington DC.

[25] Sun, Z. Q., Kang, Y. H., Jiang, S. F. (2008): Effects of water application intensity, drop size and water application amount on the characteristics of topsoil pores under sprinkler irrigation. - Agricultural Water Management 95: 869-876.

[26] US-EPA (2006): Global Anthropogenic Non- $\mathrm{CO}_{2}$ Greenhouse Gas Emissions, 19902020. - United States Environmental Protection Agency, EPA 430-R-06-003, June 2006, Washington DC, USA. Accessed 26 March 2007.

[27] Vázquez, N., Pardo, A., Suso, M. L., Quemada, M. (2005): A methodology for measuring drainage and nitrate leaching in unevenly irrigated vegetable crops. - Plant and Soil 269: 297-308.

[28] Vallejo, A., Garcia-Torres, L., Diez, J. A., Arce, A., Lopez-Fernandez, S. (2005): Comparison of $\mathrm{N}$ losses $\left(\mathrm{NO}_{3}, \mathrm{~N}_{2} \mathrm{O}, \mathrm{NO}\right)$ from surface applied, injected or amended (DCD) pig slurry of an irrigated soil in a Mediterranean climate. - Plant and Soil 272: 313-325.

[29] Wang, X. J., Wei, C. Z., Zhang, J., Dong, P., Wang, J., Zhu, Q. C., Wang, J. X. (2012): Effects of irrigation mode and $\mathrm{N}$ application rate on cotton field fertilizer $\mathrm{N}$ use efficiency and $\mathrm{N}$ losses. - Chinese Journal of Applied Ecology 23: 2751-2758.

[30] Xu, Y. X., Guo, L. P., Xie, L. Y., Yun, A. P., Li, Y. C., Zhang, X., Zhao, X., Diao, T. T. (2016): Characteristics of background emissions and emission factors of $\mathrm{N}_{2} \mathrm{O}$ from major upland fields in China. - Scientia Agricultura Sinica 49: 1729-1743.

[31] Yang, W. Z., Yang, M. D., Wen, H. Y., Jiao, Y. (2018): Global Warming Potential of $\mathrm{CH}_{4}$ uptake and $\mathrm{N}_{2} \mathrm{O}$ emissions in saline-alkaline soils. - Atmospheric Environment 191: 172-180.

[32] Zapata, N., Robles, O., Playán, E., Paniagua, P., Romano, C., Salvadorb, R., Montoya, F. (2018): Low-pressure sprinkler irrigation in maize: differences in water distribution above and below the crop canopy. - Agricultural Water Management 203: 353-365. 